\title{
Institutional Change and Persistence: The Evolution of Poland's Electoral System, 1989-2001
}

\author{
Kenneth Benoit \\ Trinity College Dublin \\ Jacqueline Hayden \\ University College Dublin
}

\begin{abstract}
Electoral systems are uniquely distributive political institutions that shape political outcomes, yet are themselves endogenously shaped outcomes of political choices. In Poland, party system development has involved not only parties adapting to electoral institutions in each election, but also parties modifying these institutions prior to every election. We model electoral system change as driven by partisan self-interest in maximizing seat share and test it in five episodes of electoral system change in Poland from 1989 to 2001, comparing parties' support for electoral law alternatives to their expectations of seat shares from those alternatives. Data consists of opinion polls, roll-call votes, Sejm records, constitutional committee transcripts, and interviews with political actors who designed and chose the Polish electoral institutions. The findings clearly show that party support for each electoral law was closely linked to the perceived effect on that party's seat share, with this linkage growing more consistent over time.
\end{abstract}

$\mathbf{T}$ he relationship between electoral and party systems, nearly all scholars recognize, is mutual: electoral institutions shape party systems, but themselves are formed in an environment of partisan electoral competition. Despite this recognition, however, electoral studies has been overwhelmingly concerned with the political consequences of electoral laws, rather than examining precisely how electoral laws themselves arise as consequences of political processes. Political experience, however, demonstrates repeatedly that while actors do maximize their self-interest by adapting their strategies in response to institutions, they also struggle to modify the institutional settings that transform their strategies into outcomes (Tsebelis 1990).

Despite its importance, this cycle of strategic adaptation and institutional modification remains understudied and incompletely understood. With the exception of a handful of case studies, the politically endogenous origins of electoral institutions has yet to receive systematic comparative treatment. Remington and Smith (1996) have examined the choice of electoral systems in post-communist Russia, Brady and Mo (1992) in Korea, and Bawn (1993) in West Germany in the postwar period. Other approaches to explaining electoral systems tend to focus on explain- 
ing variation in outcomes at a more macro level. This was the approach of the "Rokkan hypothesis" (Lijphart 1992), for instance, attributing the introduction of proportional representation (PR) in continental Europe to the extension of the franchise and the desire by established groups to protect their position while simultaneously granting a measure of representation to previously excluded groups. Such an approach also motivated Boix's (1999) examination of electoral system change in Western Europe in the twentieth century. ${ }^{1}$

Perhaps no recent event has forced more reconsideration of the endogeneity of electoral institutions than the first decade of democracy following the transitions in Eastern Europe. Nearly all examinations of the adoption of Eastern European electoral systems during their transitions to democracy indicate that electoral system design was at least partially motivated by partisan interests (Elster, Offe, and Preuss 1998; Geddes 1996; Lijphart 1992). And nowhere else has the dynamic of change in electoral institutions and party systems been observed as rapidly or as frequently as in post-communist Eastern Europe (Elster, Offe, and Preuss 1998, 130). Existing studies of electoral law origins in Eastern Europe, however, tend to focus on initial choices rather than the dynamic process of institutional adaptation by endogenous forces (e.g., Benoit and Schiemann 2001; Ishiyama 1997; Jasiewicz 1994; Kitschelt 1992). The resulting view is that while transition offers a rare glimpse at how institutions originate, once adopted, electoral institutions then adopt a more permanent tendency "to be very stable and to resist change" (Lijphart 1994, 52). Kitschelt et al.'s recent examination of party systems, for instance, considers that "over time institutions become relatively more important as exogenous determinants of democratic process features, while they are initially endogenous to the political process" $(1999,12)$.

In marked contrast, the experience of Poland examined here points to electoral institutions as simply one element in an ongoing cycle of endogenous political competition by parties struggling for distributive advantage. In just over a decade of competitive elections in Poland since its 1989 transition to multiparty elections, every election contest has been preceded by a contest among political parties to modify the electoral law, resulting in four substantively different electoral laws in the period 1989-2001. The Polish case thus provides numerous advantages for applying a theory of institutional change and persistence. First, the Polish electoral system has been widely studied before, providing a considerable store of both knowledge and prior expectations that can be applied to a theory of institutional change. ${ }^{2}$ Our focus in examining institutional choice in Poland is therefore not only on founding choices, but also on electoral system change and persistence in subsequent episodes of "normal" politics. Second, the dynamics of Polish politics since 1989 make it an especially suitable case for examining institutional change, offering a fertile but also relatively tough case

\footnotetext{
${ }^{1}$ For a fuller background of the causality debate in electoral studies, see Benoit (2004).

${ }^{2}$ See for example Chan (2001), Gebethner (1996, 1997), Kaminski (1999), Millard (1994), Olson (1993), and Simon (1996).
} 
for testing. Because the episodes of institutional change can be compared over time, Poland also provides the opportunity to observe adaptive behavior as democratic actors learn the rules and constraints of the political game. In short, if a model of electoral system change appears to fit even partially in Poland then we would consider this a successful application and urge testing of the model in other contexts.

The paper proceeds as follows. First, we outline a model of electoral system change and persistence, identifying the implications of the theory that should be observable in the Polish case. Next, we briefly describe the Polish electoral and party systems and describe the time-series data to be applied in our examination of electoral system change. Then we proceed to examine five episodes of institutional change in Poland: the transitional electoral system of 1989, the electoral laws of 1991 and 1993, a failed attempt to modify the law prior to the 1997 election, and the successful electoral change of March 2001 before the September election. Our final section reviews the episodes, assesses the theory's fit to the Polish experience, and discusses the general applicability of the office-seeking model of electoral system change and persistence.

\section{Characterizing Electoral System Change and Persistence}

Numerous approaches have been taken to explain the choice of electoral systems, ranging from instrumental motivations concerned with policy or office, to personal gain or general welfare. Additional, noninstrumental reasons might include a desire to conform to historical precedent, pressure from external actors, imposition by technocrats, or the emergence of particular institutional forms stemming from broader sociological or economic forces (Benoit and Schiemann 2001). From among these many alternatives, our approach here is to focus on the two most common instrumental approaches explored in the previous literature on electoral system origins: policy-seeking and office-seeking.

In policy-seeking explanations of electoral system origins, electoral rules are attributed to the outcome of a struggle by parties with preferences for alternatives based on the expected policy outcomes associated with the alternatives (e.g., Bawn 1993). In office-seeking approaches, by contrast, electoral system choice is more directly concerned with winning office, in order to enjoy both the direct and indirect benefits from this good. Office-seeking models have been applied to electoral system choice in post-communist Hungary (Benoit and Schiemann 2001), Russia (Remington and Smith 1996), and in post-authoritarian Taiwan (Brady and Mo 1992). In what follows, we interpret office-seeking as maximization of the seat share for one's own party in the legislature to be elected under the electoral system being considered. The office-seeking model differs from the policy-seeking model in that it specifies that each party will prefer rules which maximize its own share of legislative seats - rather than those of any other party - regardless of the compatibility of the policy goals or ideology of other parties with its own. 
On the basis of this distinction, we outline in this section an office-seeking model based on the principle of seat maximization and apply this to electoral system change in Poland from 1989 to 2001. By examining detailed evidence at each episode of electoral system change, we hope to observe implications of our model of behavior. To test whether this behavior is purely selfishly seatmaximizing, or whether policy or ideological preferences also play some role, we also examine a measure of policy positions of the parties taking sides in each episode of institutional change.

\section{An Office-Seeking Model of Electoral System Change}

Our basic model characterizing change in electoral institutions is as follows: electoral systems result from the collective choice of political parties linking institutional alternatives to electoral self-interest in the form of maximizing seat shares. Political parties will rank institutional alternatives in descending order of the expected seat shares they expect the alternative to bring them in an election to take place under those rules. In order to link most accurately institutional alternatives to self-interest, each party will seek information that will enable it to estimate the vote share it expects under each alternative electoral rule. This includes information about its own expected vote share as well as information about the operation of the electoral system alternatives for transforming this vote share into seats. A change in electoral institutions will occur when a political party or coalition of political parties supports an alternative which will bring it more seats than the status quo electoral system and also has the power to effect through fiat that institutional alternative. Electoral systems will not change when no party or coalition of parties with the power to adopt an alternative electoral system can gain more seats by doing so.

While it may seem almost obvious to expect that political parties would act in such a fashion, it is by no means self-evident that political parties do in fact behave this way when choosing among electoral law alternatives. First, especially in new democracies, actors involved in institutional choice may be driven by other motivations, in particular legitimacy, a desire to craft "good" institutions, considerations of fairness, or the fulfillment of promises made during transitional bargaining. Indeed, in the Polish case it has been argued that Polish decision makers were specifically motivated by a desire to select institutions they thought would enhance the general welfare (e.g., Chan 2001). Second, institutional decision makers may face shortages of such resources as information and understanding, given the fluidity and uncertainty of emerging party systems and a new political regime. Finally, even if their motivations were selfishly instrumental, it may be that decision makers were more concerned with ultimate policy outcomes than with immediate access to office. In our application of the model to the Polish case, therefore, we should be capable of observing and distinguishing implications of each competing explanation. 
The assumptions of the model can be enumerated more specifically as follows:

1. Each party will have an understanding of the alternative electoral systems being considered, and this understanding will be common knowledge.

2. Each party will seek information and formulate a belief about its expected vote share should an election take place, and this information will be common knowledge.

3. Each party will have a belief about its expected seat share to result from each electoral system alternative, given its expected votes and its understanding of how the electoral rules operate mechanically.

4. Each party will have a share of power to change institutions, typically determined by legislative seat share.

5. A decision rule exists for changing the electoral institutions, for instance, a majority or supermajority required in the legislature.

6. Each political party will prefer each alternative electoral system according to the seat share that it expects the electoral system to produce, given its expected votes. For each party, the electoral system alternatives that are associated with the most seats will be the most preferred.

The first three assumptions specify the parties' informational context, addressing both their relative vote expectations and their understanding about the operation of electoral alternatives in transforming votes into seats. Assumption four states that each party will have a share of power to effect alternative electoral institutions through fiat, and that this power can be assessed in objective terms such as the number or proportion of seats in a legislature. In the Polish context this "fiat power" is determined by the seats held by each party in the 460 -seat Sejm. Assumption five specifies the meta-institutional provision for changing the electoral institutions, in terms of the power metric of assumption four. In the Sejm, for instance, a majority vote is required to pass a new electoral law. The final assumption asserts the link between parties' preferences for institutions and the motivation of maximizing expected seat shares. It predicts that each party will support the electoral institution that it expects to maximize its share of seats, among the expected seat shares from all other institutional arrangements.

\section{Model Predictions}

In order to judge the Polish case as conforming to the office-seeking model outlined here, we would expect the following empirically observable model predictions to hold true in the Polish case.

1. The positions held by parties during institutional bargaining, legislative debates, or voting on electoral law bills should reflect the principle of seat

\footnotetext{
${ }^{3}$ Since the party system in Poland was rapidly changing during the period we examined-especially between elections - we consider legislative strength at specific points in time, rather than as the results of the elections themselves.
} 
maximization: no party should advocate one electoral rule over another if it expects that rule to bring it fewer seats than the alternative.

2. Electoral rules should change when some grouping of parties exists whose total legislative power is greater than the majority decision rule for changing the electoral law; and for which each constituent party expects to gain more seats from an electoral law alternative than from the status quo electoral system.

3. No electoral change should succeed absent the conditions specified in (2).

In the next section we identify and discuss the evidence necessary to test these predictions.

\section{Evidence to Examine}

The observable implications of the model point directly to the evidence that should be examined. First and foremost, we would expect that no party will support an electoral system change that it expects will reduce its own seat share. This means that we should observe parties supporting only those electoral changes that they expect will enhance their seat shares. The most direct evidence for this is in fact readily available: roll-call votes by party for the final legislative vote on each electoral law bill, recording objectively which party supported which electoral system alternative in the final event.

For evidence of parties' expectations about vote maximization, we examine public opinion polls measuring voter support for each party. For the Polish case we draw on ten years of opinion polls taken each month by the CBOS institute. ${ }^{4}$ This publicly known poll data-combined with an understanding of how electoral rules translate votes into seats - enabled each party to form an expectation for the shares of seats it would receive in an election held according to the electoral rules being considered. Combining the roll-call votes and the opinion poll information, we derive a statistic $v_{i e}$ for each party in each episode $e$. This measure $v_{i}$ is the proportion of deputies from party $i$ voting for the electoral law expected to bring a party more seats than the alternative. For each episode we can compute a summary average of $v_{i}$, weighted by the total votes cast by that party, summarizing the overall degree of conformity to the model predicting office-seeking institutional choices.

Conformity to a purely seat-maximizing model also implies that the coalitions for or against electoral law alternatives will form irrespective of the policy preferences or ideological positions of their members. Unfortunately, for Eastern European political parties it is quite difficult to obtain accurate, summary measures of ideology or policy. In Poland this problem is further aggravated by the

\footnotetext{
${ }^{4}$ These polls asked the "trial-heat" question, "if the election were held today, for which party would you vote?", taken from monthly poll reports by the CBOS Institute (Centrum Badania Opinii Spolecznej).
} 
fluidity of the parties, their members, and their policies during most of the period we observe. Making the best of things, however, we adopt scores derived from elite surveys taken in the mid-1990s by Kitschelt et al. (1999) to indicate party positions on policy on two dimensions. The first dimension is an economic-type scale of a preference for social protectionism on one hand, and for market liberalism on the other. The second dimension compares social and moral attitudes, ranging from secular libertarianism to religious authoritarianism. By comparing the two-dimensional ideological distances of parties on each side of an electoral law debate versus the expected seats each party stood to gain, we will be in a position to gauge the relative motivation of policy versus office. If the groups of parties voting together on electoral law reforms share little in common on measures of policy positions, we would take this as prima facie evidence that they were not motivated by policy-seeking concerns in their preferences for electoral institutions.

Our operational measure of policy-seeking behavior compares the average twodimensional distance of each party to the others on a particular side of the electoral law roll-call vote, comparing this to the overall dispersion of parties across the policy dimensions. We accomplish this by first computing the dimension-bydimension median $(\mathrm{DDM})^{5}$ for both the "For" and the "Against" sides on each electoral law vote. Because a basic implication of a policy-seeking motivation for institutional choice would be that the sides on an electoral law proposal share similar policy preferences, we then measure the relative policy dispersion within each voting bloc. This we accomplish by calculating the mean of party distance from each side's DDM, weighted by the number of votes cast on a particular side by that party. The greater this weighted mean-party distance from the DDM, the greater the policy differences among voting sides, and hence the greater the evidence that preferences for electoral laws are motivated by grounds other than policy. While for any given episode our measures of policy distance will only be approximations - although in our opinion the best currently available - they nonetheless provide a roughly reliable guide to whether the institutional bargaining coalitions were more or less cohesive on policy issues than the legislature taken as a whole.

These predictions and the evidence we use to assess them form the core of our testing the applicability of the office-seeking model. If the model does indeed accurately characterize the dynamic process of party and electoral system change, then its predictions should be observed in the Polish case. When these predictions are not observed, then we would consider the model test to have failed and judge it not to apply to a particular episode. Given the complex nature of insti-

\footnotetext{
${ }^{5}$ Dimension-by-dimension means have been used extensively in spatial analyses to indicate a central policy position for groups of parties in single or multiple dimensions. See Laver and Shepsle (1996) and Kadane (1972) for examples and justifications. Our DDM scores come from the median legislator position of all deputies voting on a particular side of a law during an episode (as outlined in Tables 2-5), using the position of the legislator's party as his policy score.
} 
tutional choice, in fact, we do not expect this fit to be perfect in every episode we examine, but by making its application or nonapplication clearly visible, our model acts also as a heuristic standard for understanding a specific motivation of political actors in the process of shaping and being shaped in turn by electoral institutions.

\section{The Polish Electoral and Party Systems}

In this section we outline the Polish party system and briefly describe the electoral systems in operation since 1989. The detail is limited to the essentials necessary to understand the persistence and change in the Polish electoral and party systems that it is our goal to explain.

\section{Elections and Electoral Systems in Poland}

Poland has held five elections since its transition from communism, from the semifree election of 1989 to the elections in 2001. Table 1 lists the dates of these elections and the electoral system associated with each. Since the transition to competitive elections in 1989 , every election has also been preceded by a change of electoral rules. These five episodes of institutional change (labeled as 0 through 4 in Table 1) can be examined to test how participants evaluated the proposed alternatives and whether they favored or rejected the alternatives, according to the office-seeking model we set forth.

Since 1989 when limited multiparty elections took place in single-member districts (SMDs), Poland has used a two-tier proportional representation (PR) electoral system combining multimember districts and a national compensation list. In 1992 the newly adopted "Small Constitution" specifically stated that elections to the Sejm will take place using a proportional system. The decision rule for changing the electoral law, which is considered normal legislation, is a majority vote of the Sejm. The decision rule for modifying the constitution, which would be required should (for example) proportionality be abandoned in favor of a majoritarian electoral system, is a two-thirds vote of the Sejm with at least half of the total number of deputies present. ${ }^{6}$ The same two-thirds vote is also required to override a presidential veto. The April 1997 constitution stipulates the additional requirement of an absolute majority vote of the Senate with at least half of its members present. ${ }^{7}$

\section{The Polish Party System since 1990}

Comprehensive coverage of the Polish party system - the most complicated and the most dynamic in Eastern Europe-is far beyond the scope of this

\footnotetext{
${ }^{6}$ Article 106 of The Constitutional Act of 17th October, 1992.

${ }^{7}$ Article 235.4 of the April 1997 Constitution.
} 
TABLE 1

Elections and Electoral Laws in Poland Since 1989

\begin{tabular}{|c|c|c|}
\hline Election Date & Electoral Law & Summary \\
\hline June 4, 1989 & $\begin{array}{l}\text { April 7, } 1989 \\
\text { following } \\
\text { Roundtable } \\
\text { Agreement }\end{array}$ & $\begin{array}{l}\text { (Electoral Law 0) } \\
35 \% \text { of the Sejm seats (161) contested freely using SMD } \\
\text { with majority-runoff rule. }\end{array}$ \\
\hline Oct. 27, 1991 & June 28, 1991 & $\begin{array}{l}\text { (Electoral Law 1) } \\
\text { Hare-Niemayer PR from } 37 \text { districts; } 69 \text {-seat national list. } \\
\text { Thresholds: none for districts; } 5 \% \text { for national list or } \\
\text { winning seats in at least } 5 \text { constituencies. }\end{array}$ \\
\hline - & $\begin{array}{l}\text { Oct. 17, } 1992 \\
\text { "Little" } \\
\text { Constitution }\end{array}$ & $\begin{array}{l}\text { Article } 3 \text {, Section } 1 \text {, Chapter } 2 \text { states that the principle of } \\
\text { proportionality will be the basis for the electoral law. A two- } \\
\text { thirds vote of the Sejm is required to amend the constitution. }\end{array}$ \\
\hline Sept. 19, 1993 & $\begin{array}{l}\text { May 28, } 1993 \\
\text { Passed in the } \\
\text { Sejm }\end{array}$ & $\begin{array}{l}\text { (Electoral Law 2) } \\
\text { D'Hondt PR from } 52 \text { districts; } 69 \text {-seat national list. } \\
\text { Thresholds: } 5 \% \text { nationwide for districts, } 8 \% \text { for coalitions; } \\
7 \% \text { for national list. }\end{array}$ \\
\hline - & $\begin{array}{l}\text { April 2, } 1997 \\
\text { Constitution } \\
\text { approved }\end{array}$ & $\begin{array}{l}\text { Also incorporated the principle of proportionality. } \\
\text { Amendment provision: two-thirds vote of the Sejm, plus a } \\
\text { majority vote of the Senate. }\end{array}$ \\
\hline Oct. 20,1997 & $\begin{array}{l}\text { June } 27,1997 \\
\text { Sejm vote to } \\
\text { change law failed } \\
182 \text { to } 181\end{array}$ & $\begin{array}{l}\text { (Electoral Law 3) } \\
\text { Narrow defeat of a proposal that would have introduced } \\
\text { more proportionality by changing d'Hondt formula to } \\
\text { Modified Sainte-Laguë. }\end{array}$ \\
\hline Sept. 23, 2001 & $\begin{array}{l}\text { March 7, } 2001 \\
\text { Sejm approves } \\
\text { new law }\end{array}$ & $\begin{array}{l}\text { (Electoral Law 4) } \\
\text { Modified Sainte-Laguë PR from } 36 \text { districts, no national list. } \\
\text { Thresholds unchanged. }\end{array}$ \\
\hline
\end{tabular}

paper, ${ }^{8}$ and our treatment here is limited to a brief sketch. After the break-up of Solidarity following its victory in the semifree elections of 1989, a plethora of rapidly changing political platforms and parties appeared on the scene. Following the 1990 presidential campaign some 69 parties contested the October 1991 parliamentary elections, resulting in 29 parties entering the Sejm. ${ }^{9}$ The situation stabilized somewhat following the 1993 elections when the 5\% threshold filtered out many parties. The 1997 elections continued this reductive trend, culminating

\footnotetext{
${ }^{8}$ See for example Ekiert (1992), Vinton (1993), and works cited in previous footnotes. Henceforth we will refer to each political party by its full English name followed by its Polish acronym, referring only to the acronyms in our tables, with the sole exception of the PZPR, the Polish United Workers' Party.

${ }^{9}$ The point could rightly be made that not all of these political groupings should be properly called parties. While the character of partisan grouping is of secondary concern to our analysis, we have been generally careful to refer to parties as caucuses in the text and tables which follow.
} 
FIGURE 1

\section{Polish Party Positions in Two-Dimensional Space}

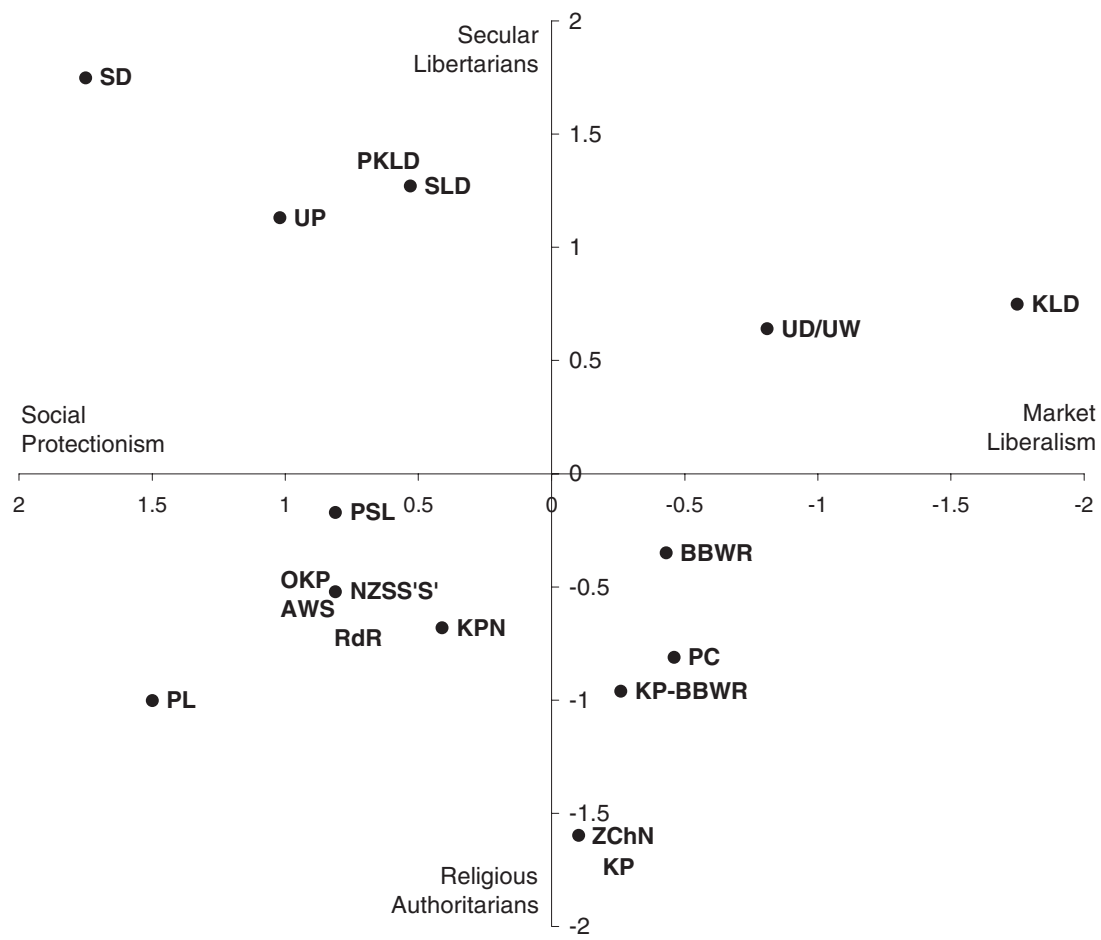

Note: Base data come from factors derived from expert survey results reported by Kitschelt et al. (1999), Table 7.1. Additional party positions not found in Kitschelt et al. are explained in footnote 10.

in the 2001 elections falling just 15 seats short of majority coalition government. Overall, popular support for the political parties, and the composition of the political party system itself, has changed considerably over time, a pattern easily confirmed by the more than 10 years of nearly monthly opinion polls we have examined from the 1989-2001 period. Our data on the ideological positions of the parties, drawn from the two-dimensional factor scores derived by Kitschelt et al. (1999) from expert surveys taken in the mid-1990s, shows as well that there is considerable variation in party positions on policy. We have reproduced these two-dimensional positions and mapped them to the additional parties in our analysis in Figure 1. ${ }^{10}$

\footnotetext{
${ }^{10}$ Kitschelt et al.'s (1999) elite survey was conducted in 1994 - the approximate midpoint of the period we examine. Not all of the parties we examine here were included in their analysis, and where noted in Figure 1 we have made several equivalencies and in two cases, interpolations. The interpolations are for the SD, scored by us at $(1.75,1.75)$; PL, assigned the score $(1.5,-1)$; and KP-BBWR in 1997, which we assigned the midpoint between KP and BBWR.
} 
The remainder of this paper examines five episodes of institutional change, using each to assess the implications of the model. These are the 1989 Roundtable negotiations over the rules for the semifree transitional elections, which we discuss as a precursor to the nontransitional episodes of institutional change; the 1991 and 1993 electoral law changes; the failed proposal to change the electoral law in 1997; and electoral law change in March 2001 that governed the September 2001 elections. Because the theory applies to "normal" politics in an established legislative system, we concentrate mostly on the episodes of change from 1991 to 2001 . The discussion begins, however, with the transitional electoral system of 1989 .

\section{The Founding Election: The Transitional Electoral System of 1989}

With the legitimacy of the Polish United Workers' Party/PZPR waning in the late 1980s in the face of economic crisis and destabilizing strikes, the PZPR agreed to semifree elections with the Solidarity-led opposition during the Round Table talks held between February and April 1989. The basic motivation of each side was straightforward. For the communists, the talks were intended to result in an arrangement that would permit Solidarity to enter Parliament but nonetheless preserve communist rule. For Solidarity, the primary motivation was legalization of the trade union. Even semifree elections, however, meant that a new set of electoral rules had to be agreed upon. To this end, bargaining over the electoral institutions took place in the context of a complex set of negotiations between the PZPR and the opposition. Neither communist nor Solidarity negotiators anticipated that the Round Table process would result in the PZPR losing power and the formation of a Solidarity government by summer's end (Olson 1993).

The agreement finally struck was the following. Formally, the party agreed to 425 Sejm seats distributed among 115 multimember electoral districts (Gebethner 1997, 384) while Senators were to be elected in all 49 provinces (two each for 47 of them and three in Warsaw and Katowice). This "compartmentalized election system" (Olson 1993) with seven separate segments of electoral competition guaranteed $65 \%$ of seats in the Sejm for the ruling PZPR coalition. ${ }^{11}$ Only $35 \%$ of the seats could be contested by nonaffiliated candidates (Gebethner 1997).

Because it took place in a transitional context outside of a normal legislative setting and because the bargaining sides were not well defined as political parties, we do not consider the 1989 case as a full case to be examined in light of the model. Electoral rules in 1989 were being negotiated not as rules to a wellestablished game, but rather as one part of an overall process of political and institutional transition from one regime type to another. The incumbent PZPR

\footnotetext{
${ }^{11}$ The seats were assigned in the following proportion: PZPR 37.6\%, United Peasant Party, ZSL $16.5 \%$, Democratic Party, SD 5.9\% with a further 5\% set aside for Christian Groupings.
} 
had proposed the single-member district majority run-off format-essentially the same rules as in previous non-competitive one-party elections-because it perceived it would do well under these rules and because employing a form of PR would have required recognizing Solidarity as a legitimate political party, something which the PZPR was not prepared to do (Kaminski 1999, 99). At the same time, the PZPR felt that it had secured its control of power relations within the Sejm by getting Solidarity to agree to the $65-35$ seat division, diminishing the importance of the issue of the rules for converting votes to seats in the minority of legislative districts that would be contested (Olson 1993; Colomer and Pascual 1994; Hayden 2001). On the other side, the opposition embodied by Solidarity was essentially uninterested in contesting the proposed electoral rules, because it saw the agreement to semifree elections as having met its primary goal at the Round Table: the relegalization of the union. Moreover, Solidarity negotiators did not regard the choice of electoral rules as important because they did not perceive the PZPR's offer of semifree elections yet as a genuinely competitive exercise offering an effective chance to govern (Staniszewska 1999). Because the electoral system was not the main prize to be won from bargaining, the political sides did not seek strictly seat-maximizing institutions. Instead, the lack of information and uncertainty, the poor definition of the political parties whose seats would be maximized, and the explicit recognition that the resulting legislature was to be transitional all caused seat-maximizing motivations to explain poorly the choice of electoral rules. Once politics became more normalized, however, this situation was to change quickly.

\section{The PR Electoral Law of 1991}

Part of the original intent during the negotiations of 1989 had been that one of the tasks of the resulting "contractual" Sejm would be to agree on a new electoral system to govern fully competitive parliamentary elections. But as the elections scheduled for October 1991 approached, the political forces that had forged the 1989 agreement were changing rapidly and dramatically. Solidarity was disintegrating into several new political caucuses and parties, the largest being the Civic Parliamentary Club/OKP. Meanwhile, the former Polish United Workers'Party/PZPR deputies had divided into four separate groups, the largest being the post-communist coalition, Parliamentary Club of the Democratic Left/PKLD later to become Social-Democracy of the Republic of Poland/SdRP. This fragmentation would profoundly influence the choice of the new electoral system.

The electoral alternatives were considered in a Constitutional Commission of the Sejm. Table 2 shows the political caucuses involved in the 1991 rule change. Debate over the new rules was dominated by the Civic Parliamentary Club/ OKP and the Parliamentary Club of the Democratic Left/PKLD; the liberalintellectual Democratic Union/UD, a post-Solidarity party which had emerged from the Civic Parliamentary Club/OKP; the rural and conservative Polish 


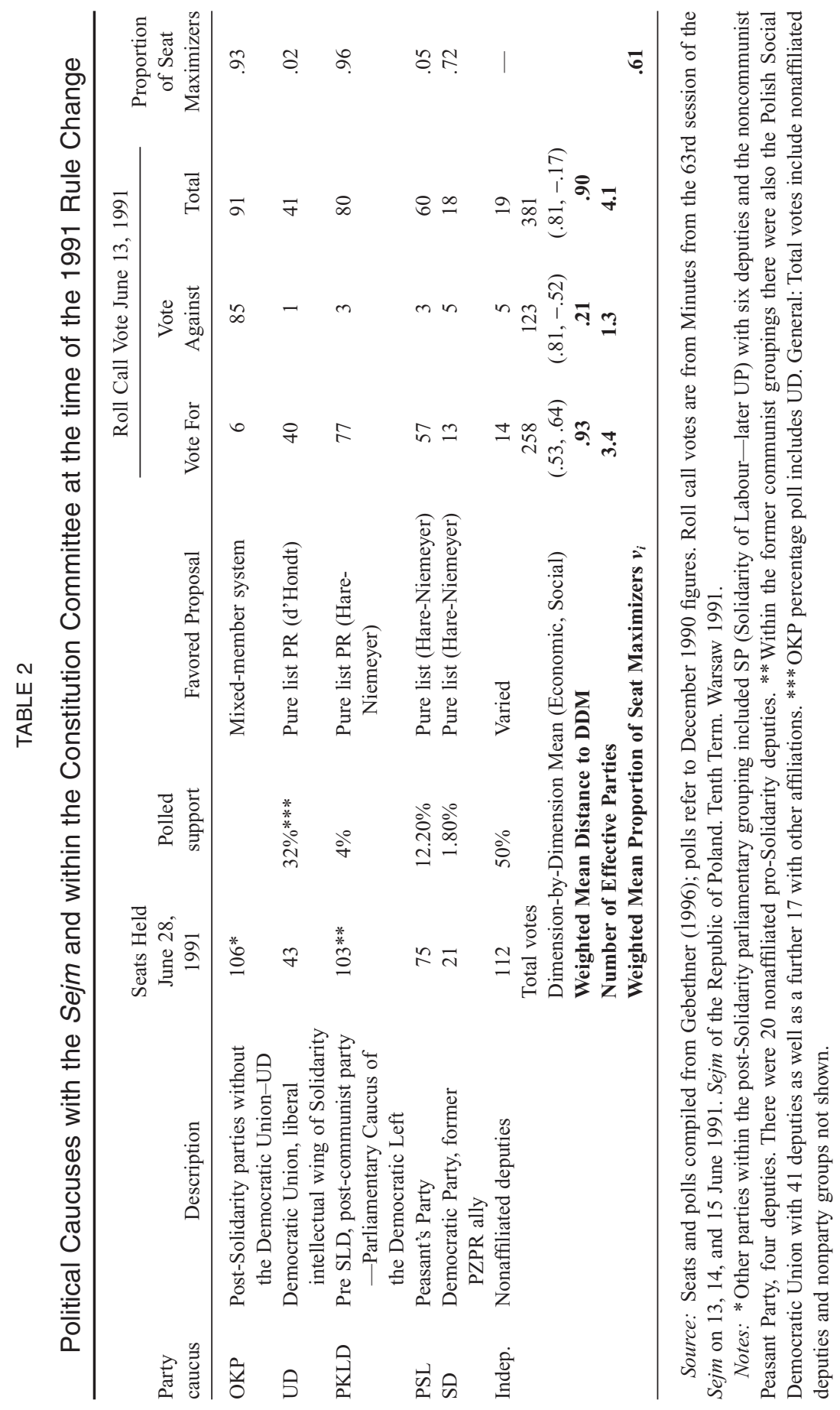


Peasant Party/PSL; and the leftist Democratic Party/SD. Two basic electoral law proposals emerged, with the Constitutional Commission favoring a PR, and Walesa proposing majoritarian rules. The general consensus, however, was that the system should be proportional (Raciborski 2000).

Conscious of their very low ratings in opinion polls and fearing future exclusion from the legislature, the post-communist Parliamentary Club of the Democratic Left/PKLD and the Democratic Party/SD both supported a pure list system using the highly proportional Hare-Niemeyer method of seat allocation. The Polish Peasant Party/PSL, a former PZPR ally, also supported the highly proportional rules, but initially with some reservations. The PSL's initial proposal in the constitutional committee debates had called for a less proportional d'Hondt or Sainte-Laguë PR formula, a 2\% threshold, and smaller districts ranging mostly between six and nine seats. ${ }^{12}$ PSL felt stronger than the other post-communist parties given its 12\% in the polls (Gebethner 1996 and Table 2). Nonetheless, in the end it threw its support behind the highly proportional system. First, the PSL was a rural party with fewer well-known leaders and a generally weak relationship with the media and lacked confidence in the polls. Second, the PSL's Aleksander Luczak, chair of the working party of the special constitutional committee on the new electoral rules, displayed a concern for appearing fair to the main post-communist interest, the Parliamentary Club of the Democratic Left/PKLD, by not excluding it from the legislature with a more restrictive system. In the end the Polish Peasant Party/PSL thus endorsed the Hare system despite its initial interest in a less proportional alternative.

The main post-Solidarity caucus, the Civic Parliamentary Club/OKP, as the largest grouping in both the Sejm and in opinion polls, supported a mixedmember system in the constitutional committee negotiations, with each voter casting a single-member district vote for a candidate, as well as a vote from multimandate constituencies for party lists allocated using the relatively unproportional d'Hondt method (Gebethner 2000). ${ }^{13}$

The post-Solidarity Democratic Union/UD endorsed the proportional system in the constitutional committee, although it had initially supported some version of a plurality method. Many of the UD deputies were well-known Solidarity heroes and felt that they could do well in a plurality system. In addition, the party perceived itself as relatively strong electorally with $14-15 \%$ ratings in the polls. The UD therefore calculated that if the system were to be PR, then the less proportional d'Hondt allocation formula would be more to its advantage than Hare-

\footnotetext{
${ }^{12}$ Document number 22 of the Constitutional Commission, 5 Feb 1991, p. 16.

${ }^{13}$ The d'Hondt formula is one of a number of mathematical methods for converting seats into votes under systems known as proportional representation. The common understanding of the Polish decision makers followed the conventional wisdom in electoral studies, namely that the d'Hondt system is the least proportional and most favorable to large parties, followed by the Sainte-Laguë, the modified Sainte-Laguë, and finally the Hare/Hare-Niemayer formula, with the last resulting in the greatest proportionality and favorability to smaller parties. See Benoit (2000) for details on the proportionality of various formulas.
} 
Niemeyer (Litynski 2000). The UD eventually relented, however, in favor of HareNiemeyer as a concession to the former communists. As Democratic Union/UD member Jan Litynski (2000) points out, this desire to accommodate the postcommunist interests stemmed from agreements struck during the Round Table process.

The Union of Labor/UP was a left-wing offshoot of Solidarity. It had also emerged from the Civic Parliamentary Club/OKP and likewise PR, as did the Confederation for an Independent Poland/KPN (a non-Solidarity opposition party led by opposition veteran, Leszek Moczulski). The Democratic Party/SD also supported the proportional variant of the law.

President Lech Walesa opposed the proportional system and used his veto twice to override the Sejm's vote for a proportional law. ${ }^{14}$ Both he and cabinet leader Jaroslaw Kaczynski (later the leader of the Center Alliance/PC) favored single member constituencies and the first-past-the-post system. Walesa was concerned by the scale of fragmentation after the "War at the Top"15 and wanted to decrease the number of parties. Both Walesa and Kaczynski supported the majoritarian system because they thought it would facilitate the presidential system they hoped to engineer (Winczorek 2000). When it became clear that PR was going to win out, however, Walesa then argued for the less proportional Sainte-Laguë method for both constituencies and the national list, hoping to boost the representation of medium-sized parties (Chrusciak 1999, 6; Winczorek 2000). At worst, Walesa was prepared to tolerate a mixed system but the Sejm overturned his veto by the two-thirds majority required, and he eventually signed the new law on 28 June. ${ }^{16}$

In the end, the highly fragmented Sejm eventually accepted the Hare version of PR - considered by all to be the most proportional of PR formulas - instead of the Sainte-Laguë or d'Hondt methods, and it rejected adopting a threshold. The fragmented parties were clearly afraid of legal thresholds and seat allocation methods that favored larger parties (Gebethner 1996, 68), although they did agree to a $5 \%$ threshold and Sainte-Laguë for the national list.

Reviewing the positions of each party, we generally see the parties expecting the most votes favoring the least proportional proposals. The most popular grouping was the Civic Parliamentary Club/OKP, polling 32\% of the expected vote in December among those intending to vote for a party (Gebethner 1996), leading President Walesa to hope he could harness the post-Solidarity vote behind a pop-

\footnotetext{
${ }^{14}$ A two-thirds majority of the Sejm is required in order to overcome the Presidential veto.

${ }^{15}$ Lech Walesa is attributed by some Solidarity activists with forcing a "war at the top" of the union in order to assert his control. Walesa himself claims that he was trying to force the creation of a party system in Poland.

${ }^{16}$ The law signed by President Walesa on June 28, 1991 had been passed by the Sejm on May 10th and ratified by the Senate on May 23rd. Initially, President Walesa refused to sign the law and returned the bill to the Sejm. On June 13 the Sejm discussed the president's objections. Of the 397 deputies who cast their vote, 257 voted for the new law, 123 were against and 16 abstained (with 1 invalid vote), meaning the law failed to pass since the qualified majority of 264 was not reached. This particular vote was a roll-call vote, and it is on this episode that Table 2 is based. See Chrusciak (1999).
} 
ulist rightwing presidential style party that he would in effect control. As the party with the most to gain from a restrictive system, the OKP hence followed the principle of seat maximization by supporting the mixed system and later the d'Hondt formula. Among the smallest parties, the post-communist Parliamentary Club of the Democratic Left/PKLD and the Democratic Party/SD perceived that they would have been eliminated were a threshold introduced, so their support for pure list and Hare-Niemeyer is consistent with seat-maximizing behavior.

Two parties, the Polish Peasant Party/PSL and the Democratic Union/UD, did not behave in a strictly seat-maximizing fashion. The PSL supported the highly proportional Hare-Niemeyer despite indications it would have gained a greater seat share with a less proportional alternative. Likewise, the post-Solidarity UD's eventual support for the Hare-Niemeyer was also not seat maximizing. Polls indicated that the Democratic Union/UD had $14-15 \%$, and this motivated its early decision to support d'Hondt. Its eventual acceptance of the Hare-Niemeyer proposal grew out of the context of its Round Table agreements with the former communists. The UD did not wish to renege on that agreement by voting for a formula or threshold that would have resulted in the post-communist Parliamentary Club of the Democratic Left/PKLD being excluded from the new parliament (Litynski 2000).

The 1991 episode conforms only partly to the model predictions, therefore, as a consequence of lingering transitional issues and the irregularity of the party system still very much in evidence in early 1991. Nonetheless, on balance parties were still generally seat-maximizing in their stances on the Hare-Niemeyer electoral law bill. Furthermore, the coalitions of parties forming for and against the final bill were not at all congruent on matters of policy preferences. On the "For" side, proponents ranged across the spectrum of policy, from the liberal and secular Democratic Union/UD to the highly socially protectionist former communist Democratic Party/SD and the post-communist Parliamentary Club of the Democratic Left/PKLD. For the 3.4 effective parties supporting the "For" vote, there was a weighted mean distance to the DDM of .93-greater than even the weighted mean distance to the DDM for all of the parties of .90 (Table 1). Even for the deputies voting "Against," the distance to the DDM was .21, a considerable spread given that effectively only the Civic Parliamentary Club/OKP opposed the bill. From this evidence, it seems clear that the preferences for electoral system alternatives in the 1991 episode were not motivated by any observable policy-seeking motivations.

In the final event, the Hare-Niemeyer PR bill passed for several reasons. First, only the highly proportional Hare PR formula could generate a minimumwinning coalition that could secure passage, especially after Walesa's veto of the first version of this bill raised the passage threshold to a two-thirds majority. Since most of the seats were held by parties expecting low vote shares, the proportional rules were the only ones attractive to the many smaller parties whose support was required for passage. Second, uncertainty over expected votes made the highly proportional system the most attractive to the most parties. Given the still tran- 
sitional context, not only were expected votes difficult to calculate but also the parties themselves were still undergoing significant change and realignment. Solidarity (the Civic Parliamentary Club/OKP) in particular was not a traditional party but rather a collection of political forces that would soon splinter into numerous other parties (as indeed happened on the eve of the 1991 elections). Evidence strongly indicates that parties understood the workings of the electoral laws and were aware of alternatives, but because of the still transitional context were uncertain of their expected votes. Finally, remaining legacies of the transition made some parties, namely Democratic Union/UD and Polish Peasant Party/PSL, still unwilling to pursue complete seat-maximization at the cost of antagonizing the former regime parties. The more moderate Solidarity wing was still afraid that democracy might be endangered if the opposition were to renege on informal commitments made at the Round Table negotiations. This motivation is not consistent with the predictions of the office-seeking model, but is congruent with the problems of the transitional context that dominated the 1989 episode.

\section{The More Restrictive PR Electoral Law of 1993}

The 1993 rules arose out of the 1991 episode that had produced a highly fragmented parliament of 29 caucuses in the Sejm with some 60 deputies elected from small parties (Litynski 2000). The two biggest parties, Democratic Union/UD and the Alliance of Democratic Left/SLD (a second-generation postcommunist party formed from the Parliamentary Club of the Democratic Left/PKLD) had won only 62 and 60 seats respectively (out of 460) in the 1991 election, making it necessary for seven or eight parties to agree to manufacture a majority. Social and moral debates, including a heated contest over abortion, combined with the usual tensions of economic transition, produced a highly fractious and tense period in Polish politics. The result was to push forward on the institutional agenda a more restrictive law that made effective governance more plausible.

The preparatory work on the new electoral law was based on a bill submitted by the Democratic Union/UD. As the two largest parties in the Sejm, the Democratic Union/UD and the Alliance of Democratic Left/SLD led the call for the introduction of thresholds and were joined by the Liberal Democratic Congress/KLD (absorbing the Polish Liberal Program/PPL) in supporting d'Hondt. Consensus emerged as these three parties were joined by the Polish Peasant Party/PSL and the nationalist Confederation for Independent Poland/KPN on the need for a less proportional electoral law. These were the largest parties to have won seats in the 1991 elections and also those groups holding the largest shares of seats during the electoral law debate in 1993 (see Table 3). Feeling relatively confident of electoral success, these "great four" parties favored the less proportional d'Hondt formula, smaller constituencies, and the introduction of a threshold (Gebethner 2000). 
Institutional Change and Persistence

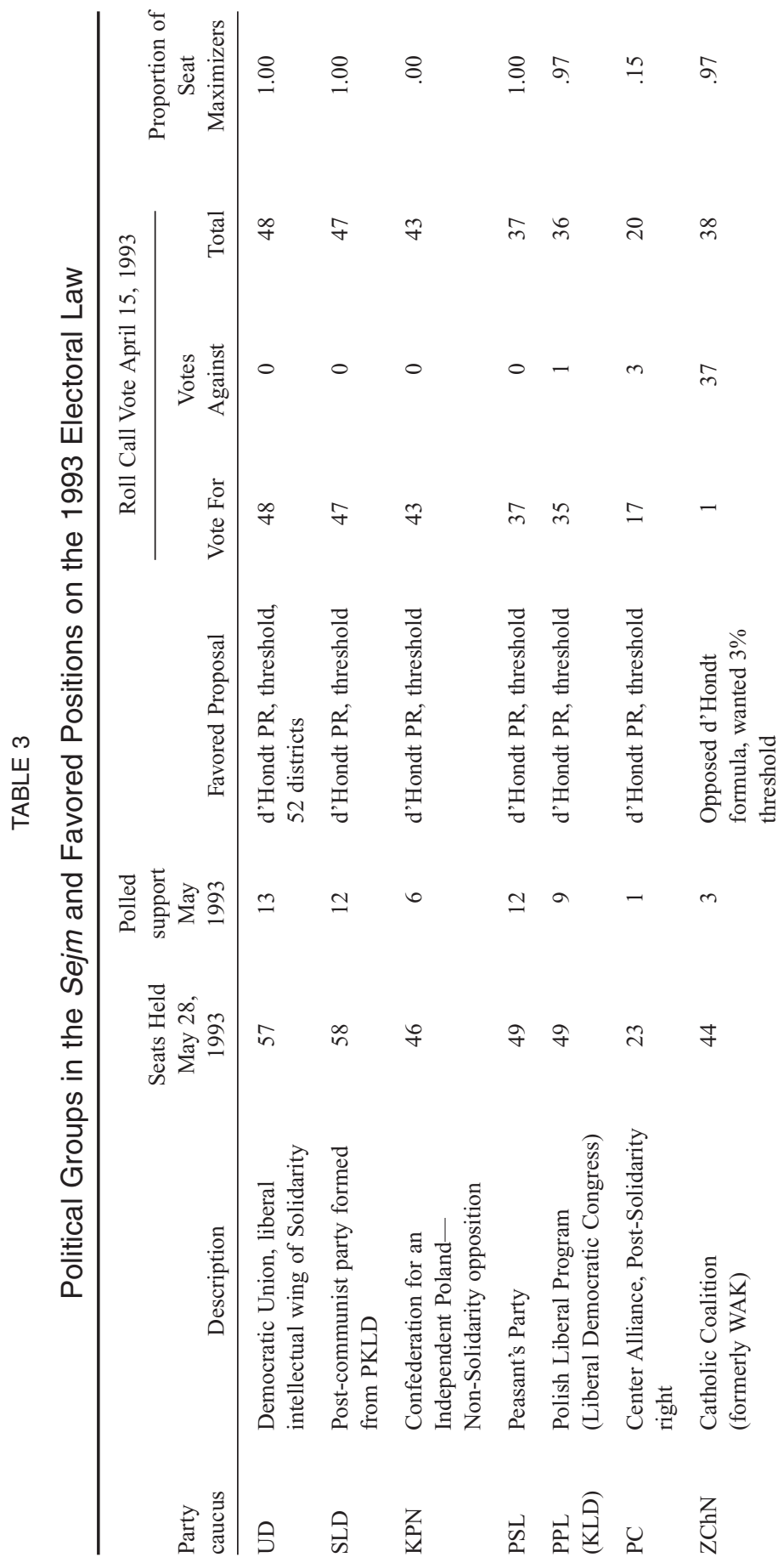




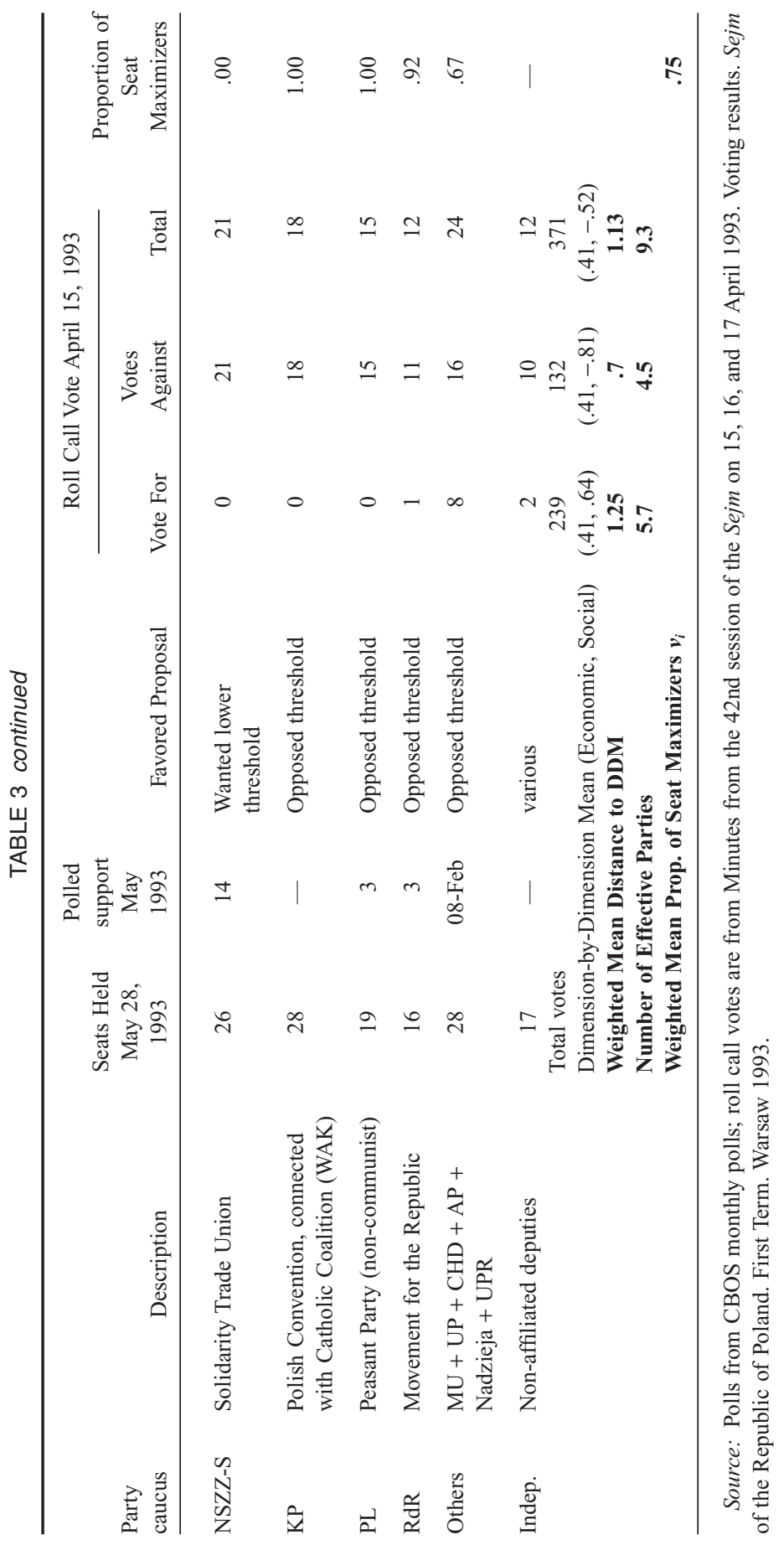


The Sejm voted on April 15 to pass the new electoral ordinance. ${ }^{17}$ The law introduced a $5 \%$ threshold for individual political parties, along with an $8 \%$ threshold for coalitions and a 7\% cutoff for the 69 national list seats. The d'Hondt method replaced Hare-Niemeyer and the structure of the electoral districts was changed, increasing from 37 multimember to 52 multimember districts, with between 3 and 17 mandates (Chrusciak 1999).

Parties who perceived a threat to their seat share from the more restrictive measures generally opposed the introduction of thresholds and the d'Hondt system. The Christian National Union/ZChN (which had run as WAK/Catholic Electoral Action in the 1991 election) was highly critical and suggested that the thresholds for parties, coalitions and the national list be reduced to 3.6 and $5 \%$ respectively. Although the ZChN held 44 seats in 1993, it was polling only $3 \%$ in the polls at the time and feared it might not pass a higher threshold. ${ }^{18}$ The Movement of Poland/RdR was the most critical of the bill, vehemently opposing thresholds, reduced proportionality, and the national list rewarding larger parties. The postSolidarity leftist Labor Union/UP, with just four seats, also opposed the electoral law, the pro-large party measures of which were described by party leader R. Bugaj as an "outright swindle" (Chrusciak 1999). All of these parties were receiving fewer than 3\% in the trial heat polls held in May 1993. One exception to the seatmaximizing behavior is the NSZZ-Solidarity trade union, who despite reaching 8\% in the May 1993 opinion polls nonetheless favored a lower threshold.

As a whole we see much more conformity to the seat-maximizing model in 1993 than in previous episodes. On balance, the parties expecting the most seats, as measured by the polls on the eve of the electoral law modification, supported the change towards a less proportional system that would exclude smaller parties. Conversely, the smaller parties expecting fewer votes opposed the change. The only exceptions were the remaining post-Solidarity parties Centre Alliance/PC and NSZZ-Solidarity. In the case of PC, which the polls indicated would receive only $1 \%$ of the vote, the support for the more restrictive law was simply not seatmaximizing. There is evidence, however, that PC leader Jaroslaw Kaczynski believed in 1993 that the polls severely underestimated the support for his party. ${ }^{19}$ In the case of the NSZZ-Solidarity, a party closely allied to Walesa, the party supported a lower threshold despite polls showing it could pass the $5 \%$ level. The unity of this party was uncertain, however, given its previously demonstrated propensity to fragment. ${ }^{20}$ Finally, the Confederation for Independent Poland/KPN

\footnotetext{
${ }^{17}$ Its passage into law occurred on May 28, 1993.

${ }^{18}$ There is also evidence that $\mathrm{ZChN}$ felt that the polls underestimated its support, yet nonetheless opposed the new law because it allowed Saturday, in addition to Sunday, as the possible election day. ZChN feared the loss of the "Sunday Mass" effect would reduce its vote share (Kaminski 2001).

${ }^{19}$ Which proved to be correct, although with only $4.5 \%$ of the vote the PC did not attain the threshold. See Kaminski (2001).

${ }^{20}$ In addition to the NSZZ Solidarinosc, there were two other parties, NSZZ-"80" (Solidarity "80") and NSZZ-"I" (Solidarity Trade Union of Individual Farmers), with just 4\% and 2\% in the polls respectively. Given that none of these parties in fact won seats in the 1993 election, their opposition in retrospect to the law is perfectly consistent.
} 
supported the more restrictive law despite a borderline showing $(6 \%)$ in the polls. Incidentally, all three parties-NSZZ-S, PC, and KPN—ceased to exist following the 1993 election. Generally, however, the parties "from the point of party interest ... were absolutely rational. [There were] errors of judgment, but this did not exclude rationality" (Gebethner 2000). The few exceptions to the model's predictions came from parties who discounted the information on expected votes presented by the opinion polls, or from pseudo-parties like the Walesa-allied Solidarity bloc which foresaw its own fission into smaller electoral units.

Examining the policy congruence of the voting blocs, it is also clearly visible that the roll-call voting for the 1993 electoral law did not conform to any recognizable policy-seeking explanation. This pattern was most evident in the side pushing for adoption of the bill, with a weighted mean distance to its DDM of 1.25 - once again even higher than the overall distance to the DDM of 1.13 (Table 3). The "For" grouping, combining liberals, former communists, and populist peasant parties, was clearly not formed on the basis of any consistency of policy preferences, but rather on the basis of their expected votes which translated directly into seat-maximizing concerns. Despite informational flaws and uncertainty caused by the highly dynamic party system, by 1993 most parties were using seat-maximization as the basis for selecting among electoral system alternatives.

\section{The Near-Change of 1997}

As in the other episodes we examine, the 1997 attempt to change the electoral law preceded a legislative election by only a few months. Unlike the other attempts, however, final passage of the electoral law was not secured. This failed attempt therefore presents a unique case of institutional nonchange to which we can apply the model, since the model's observable predictions also encompass failed attempts to modify institutions.

The electoral law bill introduced in 1997 was an attempt to make the electoral system more proportional. Since late 1996, legislative power had been concentrated in the hands of two parties, the socially conservative but economically interventionist Polish Peasant Party/PSL and the Alliance of Democratic Left/SLD, between them controlling more than two-thirds of the seats by the end of the parliamentary term. Despite its sizable legislative faction, however, the PSL's ratings in the polls had sharply dropped in 1996. In contrast, support for its main opponents was steadily rising, in particular that of the SLD and the newly formed Solidarity Electoral Action/AWS, a coalition of post-Solidarity parties. Seeking to cut its losses in the imminent election, the PSL therefore introduced a proposal in late 1996 to replace the d'Hondt allocation method with the more proportional Sainte-Lague method. ${ }^{21}$ This proposal was also supported by the third largest group in the Sejm, the Freedom Union/UW (formed from the

\footnotetext{
${ }^{21}$ Document number 2144, 26 Sept. 1996.
} 
Democratic Union/UD and elements of the Liberal Democratic Congress/KLD), who also expected single-digit vote share. Despite their quite different political orientations, the Polish Peasant Party/PSL and Freedom Union/UW found a common interest in the proposed change (Litynski 2000). This proposal did not go to a vote, however, and expired when the Sejm recessed. A similar proposal was introduced by the Labour Union/UP in February $1997 .{ }^{22}$ This proposal sought to replace the d'Hondt formula with Modified Sainte-Laguë, also viewed as more favorable to smaller parties than d'Hondt. The bill also would have placed limits on election campaign expenditure, further mitigating the large-party bonus. Other non-Solidarity Electoral Action/AWS parties such as the Non-Party Bloc for the Support of KP-BBWR also supported the bill, since their vote expectations were next to zero.

Opposing the bill were the largest expected vote winner, the post-communist Alliance of Democratic Left/SLD, and its main opponent, the nascent Solidarity Electoral Action/AWS. This umbrella group had been formed in June 1996 to fight the 1997 election against the post-Communist parties. At the time of the vote on the final bill, the AWS officially controlled only 16 seats (June 1997), although the smaller parties that would later join AWS collectively held several times this number. ${ }^{23}$ For this reason, nearly all of the smaller parties that would later join the AWS opposed the bill, joining forces with the SLD in opposition to the Labour Union/UP proposal, on the basis of AWS's strong showing in the opinion polls. ${ }^{24}$ Ultimately, the UP electoral bill was defeated in the Sejm in June 1997 by the combined vote of the SLD, AWS, and the AWS-inclined rightist parties. Although a new electoral law was passed the following day (June 27), it made no essential changes to existing procedures. ${ }^{25}$

The 1997 episode provides the clearest example yet of seat-maximizing manipulation. In this case a coalition of all parties except Alliance of Democratic Left/SLD and Solidarity Electoral Action/AWS attempted to pass an electoral alternative that would have provided more seats for smaller and medium-sized parties than the status quo (d'Hondt) rules, which failed to pass since the SLD, the AWS, and the AWS-allied parties were solidly against it. The AWS, although small with only 16 seats at the time of the vote, anticipated being a big party in the next legislature given its $21 \%$ in the polls. The parties in the "Other" category (Table 4) likewise considered that they would gain more seats with the less

\footnotetext{
${ }^{22}$ Document number 2203, 6 February 1997.

${ }^{23}$ The configuration of parties in the 1993-1997 Sejm is therefore somewhat misleading, as most of the $35 \%$ of the unrepresented voters had supported post-Solidarity right-wing parties and electoral coalitions. The main right-wing parties actually won $29.24 \%$ of the vote in 1993 which was lost because of the high degree of fragmentation. These parties went on to form the AWS coalition which secured nearly $34 \%$ of the vote in the 1997 election.

${ }^{24}$ Parties such as "Fatherland" Catholic Election Committee list, KPN, BBWR, PC, PSL-PL, and NSZZ-S, which were all represented in the 1993 Sejm, joined AWS when it was formed in 1996.

${ }^{25}$ The main idea was to limit the number of parties by making the conditions for registration more onerous. According to the new law the application for legal registration of a new party must be supported by at least one thousand adults.
} 


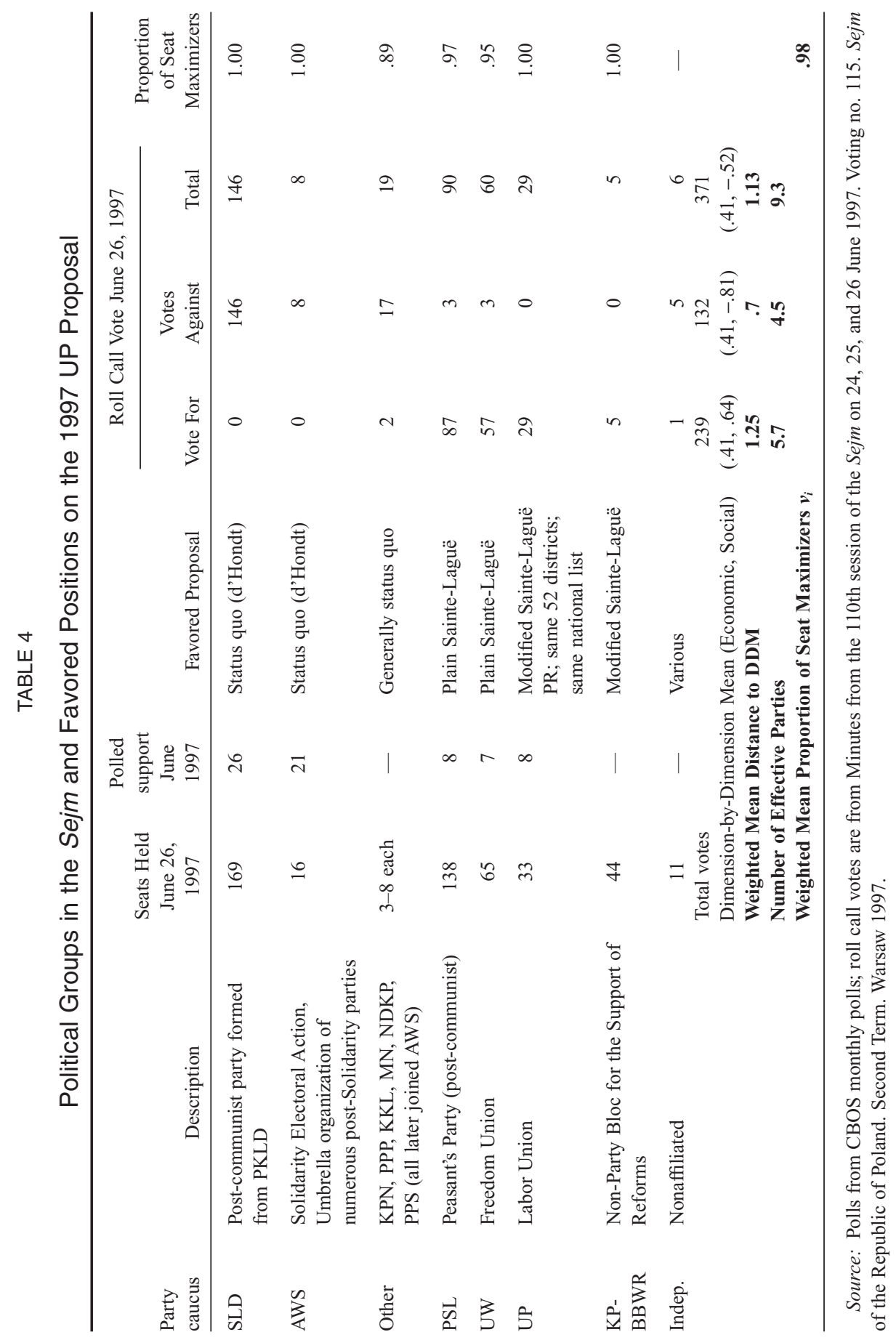


proportional d'Hondt since they anticipated joining AWS in the election. Given the polls and the expectations at the time, the positions taken and the outcome of the vote fits squarely within the model predictions.

The 1997 episode underscores the model's predictions of the preeminence of seat-maximization in relation to other, policy-seeking motivations for institutional choice. On both sides of the bill were parties aligned together whose policy objectives were essentially incompatible. The post-communist Polish Peasant Party/PSL and the liberal Freedom Union/UW joined forces to support the measure, while the main competitors Alliance of Democratic Left/SLD and Solidarity Electoral Action/AWS conspired to bloc the bill's passage. As with previous episodes, from a policy standpoint the strangest bedfellows were on the "For" side of the bill, with a weighted mean distance to the DDM of .83 nearly as great as the policy distance of all parties of .87 (Table 4). And while not revealed by the simple quantitative measures, on the "Against" side the SLD and the AWS coalition paired essentially the two key rival forces in the party system, the former being the primary post-communist party and the latter the main post-Solidarity grouping. This odd alliance was joined for no other purpose than the objective of maximizing seat shares.

\section{1: Sejm Change, Different Outcome}

Opportunity for changing the electoral law in 2001 came from a new administrative division of Poland introduced on January 1, 1999, leading to a general feeling that the electoral districts needed adjustment to bring them into line with the new administrative units. Proposals to modify the d'Hondt PR system with 52 districts and a 69-seat national list (existing since 1993) submitted by the Alliance of Democratic Left/SLD, the Polish Peasant Party/PSL, Freedom Union/UW, and Solidarity Electoral Action/AWS, however, differed widely in their anticipated distributional consequences.

The Alliance of Democratic Left/SLD was the second largest party in the Sejm during the 2001 episode, but it was also the highest in the polls. Since the year following the 1997 election, support for the SLD had been steadily increasing, while that of Solidarity Electoral Action/AWS steadily and dramatically declined. Reflecting its standing in the polls, the SLD proposed essentially to preserve the status quo system. ${ }^{26}$ It would have kept the 69 -seat national list viewed as favorable to the largest parties, although slightly modifying the regional basis for its allocation. The remaining 391 seats would be distributed from 52 districts of 5-12 candidates, using the existing d'Hondt formula. The SLD claimed that this new structure of electoral districts would guarantee a just representation also for those parties with between 8 and $15 \%$ of the vote. At the same time, the new national list rules would favor the largest parties.

\footnotetext{
${ }^{26}$ Document number 1229, July 11999.
} 


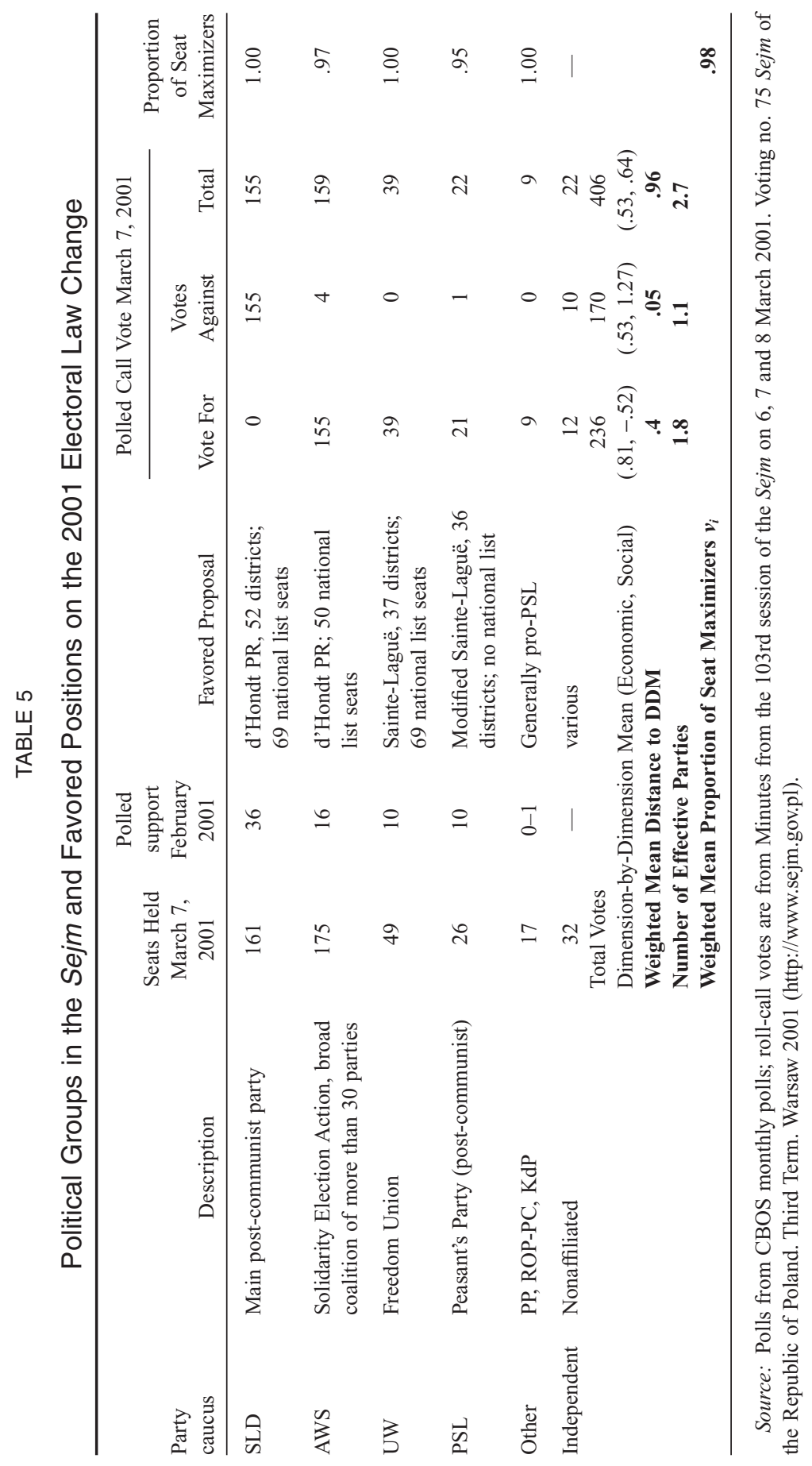


Solidarity Electoral Action/AWS, the main competitor to the SLD, like most other parties generally favored changing the electoral law to make it more proportional and less rewarding to the largest party. AWS had seen its poll support drop from nearly a third in 1997 to half that by the end of 2000 . With the drop in support also came internal tensions, leading to the preparation of draft electoral laws by two separate factions within AWS. The so-called social movement wing of AWS called for reducing the size of the national list to 50 seats (from 69 ) and reducing the number of electoral districts, in order to increase district magnitudes to a range of $6-12 .{ }^{27}$ This proposal supported the retention of the d'Hondt formula. A second draft was produced by the Solidarity Electoral Action conservative wing (AWS-SKL). The AWS-SKL draft $^{28}$ proposed keeping the d'Hondt system, but increasing district magnitudes by reducing the number of districts to 50 and by abolishing the national list. This would have increased the size of the districts to 10-19 seats each, resulting in more proportional outcomes than the status quo system. The abolition of the national list would also have reduced the bonus to the largest party.

The Freedom Union/UW proposal also called for reducing the number of districts (to 37) and proposed the introduction of the more proportional Sainte-Laguë formula. ${ }^{29} \mathrm{UW}$ favored the retention of the 69-seat national list but called for its allocation to be determined also by the Sainte-Laguë method. A similar proposal was put forth by the Polish Peasant Party/PSL, stipulating that 460 seats would be distributed among 36 multimember districts ranging in size from 7 to 19, with no national list. If this proposal did not gain a parliamentary majority the PSL additionally proposed that six additional districts would be created. This would make 43 electoral districts (one extra created from a division of one voivodship) ranging from 6 to 16 in size. The PSL draft proposed that modified Sainte-Laguë be introduced to replace d'Hondt.

The final bill evolved largely from the Freedom Union/UW and Polish Peasant Party/PSL proposals, calling for a reduction from 52 to 36 districts, abolishing the national list, and changing the allocation method from d'Hondt to Modified Sainte-Laguë. All of these changes would have increased the proportionality of the result and reduced the seat bonus of the largest party - then universally perceived to be the Alliance of Democratic Left/SLD. The final vote on March 7 basically aligned all other parties against the SLD, each voting with almost perfect unity for the version it expected to bring it a greater seat share. For the SLD, this was the status quo system; for all other parties, this was the bill introducing greater proportionality. ${ }^{30}$

The 2001 episode was essentially a replaying of the 1997 episode, except that this time the non-SLD coalition passed the change making the system more pro-

\footnotetext{
${ }^{27}$ Document number 1935, 1 October 1999.

${ }^{28}$ Document number 1390, 29 Sept. 1999.

${ }^{29}$ Document number 1391, 9 September 1999.

${ }^{30}$ For further details on the vote, see Warsaw Voice March 18, 2001, p. 7.
} 
portional and less favorable to large parties. The key difference was that in this episode, with its support in the polls waning, Solidarity Electoral Action/AWS supported the change to greater proportionality which it had opposed in 1997 when its electoral fortune was waxing. Having paired with its post-communist rival in the 1997 vote, AWS now joined in voting for the change with the liberal Freedom Union/UW and the post-communist Polish Peasant Party/PSL — parties with whom it had very little in common on policy preferences. While the weighted distance to the DDM of each side is smaller in 2001 than in previous episodes, it should be noted that the effective number of parties on each side was also much smaller, even to the point of being essentially a single-party bloc "Against" the proposal. As with previous bills, the advocates of change were the most ideologically diverse (Table 5).

Just as in the 1997 episode, the full story emerges only when looking at Solidarity Electoral Action/AWS's expected seats, rather than its actual seats held during the episode. Its actual seats made the AWS the largest group in the Sejm, but as Litynski explained during the episode itself, "according to the polls the AWS is not a big party. [They] know that a non-proportional electoral law will destroy them" (2000). In this context the AWS and all other non-SLD parties perceived they could gain more seats with a more proportional law. Once again, the logic of office-seeking forged an unlikely partnership in support of the electoral system change, explaining the striking similarity of the proposals by the Freedom Union/UW and the Polish Peasant Party/PSL, two parties with quite different policy objectives. In the end, electoral logic alone prevailed, and the coalition of small parties seeing more expected seat share in the new law easily gathered enough votes to override the Alliance of Democratic Left/SLD's 0-155 vote against, and the measure passed.

\section{Discussion}

Our examination of the Polish case has traced the evolution of the Polish party and electoral system since its transition in 1989. Drawing from a variety of direct and indirect evidence, we have applied an office-seeking model to five episodes of institutional change in Poland. The basic finding is that while the transitional episodes fit rather poorly, as legislative and party politics becomes more normalized, the office-seeking model increasingly explains the process of institutional change and persistence in Poland. The transitional setting fits poorly for several reasons, mostly because the assumptions of the model about the informational context and about the clear identities and interests of parties did not apply well to the fluid conditions of the Polish transition. While this is not necessarily a feature of transitions from communism - for instance Benoit and Schiemann's (2001) account of the Hungarian transition showed a high degree of seat maximization in the Hungarian case - the payoff structure from bargaining was too different in the partially competitive 1989 Polish episode for seatmaximizing motives to have dominated institutional choice. 
In institutional choice involving the first fully competitive electoral system in 1991, Polish decision makers were already guided by objectives that were clearly office-seeking. Even in the face of uncertainty and limited knowledge, parties attempted to gain seats through institutional manipulation or were guided in choosing among institutional alternatives by the principle of maximizing seat share. This logic was followed even when parties risked being wrong, as did the Confederation for an Independent Poland/KPN in 1991. As partisan identities and interests form more clearly, and as information becomes more reliable, seat-maximizing behavior quickly dominates the struggle for electoral institutions. As experience accumulates, parties become more boldly and more consistently seat maximizing in their manipulations of the institutions. Figure 2 compares the overall degree of seat-maximizing behavior to our measures of policy congruence measured in each episode. The average seat maximizing behavior $v_{i}$, starting from .61 in 1991, rises to .75 in 1993, and to .98 in 1997 and 2001. Not only does the typical party more closely conform to the model, but the dispersion in $v_{i}$ by party declines with each episode, visible from interquartile range plotted with the average $v_{i}$. At the same time, we observe that not only is policy congruence among electoral reform coalitions in each episode

\section{FIGURE 2}

Seat Maximization and Policy Coherence Compared, 1991-2001

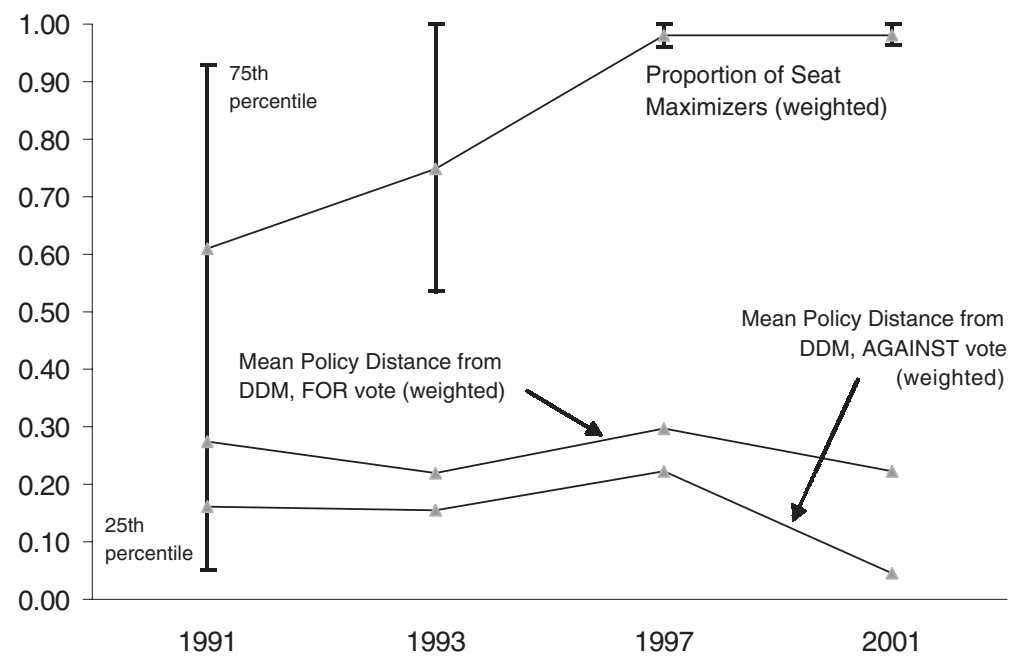

Note: Constituent data for seat maximization comes from $v_{i}$ from Tables 2 to 5 ; the points are weighted means. The upper and lower bars on seat maximization represent the 25 th and 75 th percentiles of all parties. The policy distances measures are the mean party distances from the dimension-by-dimension means (as per Tables 2-5), divided by the effective number of parties in each of the FOR and AGAINST voting coalitions. 
quite low in absolute terms, but also that there is no clear trend towards greater convergence that cannot be attributed to a simple reduction in the number of parties.

We also observe that parties that do not conform to the seat-maximizing logic of institutional choice are quickly eliminated. For instance the Center Alliance/PC who had supported a more restrictive law in 1993, despite its extremely low support in the polls, ceased to exist as a party following the 1993 election. The Confederation for an Independent Poland/KPN also harmed itself in that election by having favored a less proportional formula than its polled support warranted. In general, the model's increasing fit over time comes from a self-realizing dynamic of electoral system and party system change: parties over time must be seat-maximizing in order to continue to exist as legislative groups. Parties that do not follow a seat-maximizing logic are consequently eliminated because parties that do understand the logic of institutional manipulation apply this process to exclude or eliminate the others. Even among those parties attempting to maximize their seat shares, the punishment for miscalculation is frequently elimination from the contest.

It should also be pointed out that the coalitions for or against various electoral law bills formed solely on the basis of seat maximization, even when these groupings comprised parties whose policy goals were incompatible. In more than one episode we saw ideologically opposed parties, such as the post-Solidarity Solidarity Electoral Action/AWS and the post-communist Alliance of Democratic Left/SLD (1997), or the liberal and urban Freedom Union/UW and the conservative and rural Polish Peasant Party/PSL (1997 and 2001), vote in similar ways on electoral law bills solely because they perceived a similar profile of electoral costs and benefits. Parties in Poland made institutional decisions above all in order to consolidate their own electoral positions, apparently without regard to whether this also improved the position of their greatest opponents or worsened the position of ideologically closer parties. This is compelling evidence that the primary decision rule for parties facing institutional choices is office- rather than policy-seeking.

Another remarkable finding is that even in the transitional and highly volatile Polish political situation, parties displayed an extraordinary degree of cohesion during episodes of institutional choice. In nearly every episode, every party we examined voted as a bloc with almost no dissenting members. The few parties who did experience minor rates of dissenting votes tended to be loose coalitions of parties or very small parties. These results suggest that although parties typically comprise (and express) many views and interests, when choosing distributive political institutions the Polish parties essentially behaved as if they were unitary actors. This is all the more remarkable given the unusually high volatility of the Polish party system, during a period when party memberships and party identities were constantly and radically shifting. This also points to the need for distinguishing between actual support for electoral law measures - such as roll-call votes - and more rhetorical statements of individual representatives 
of parties which may be mistaken for party positions or preferences on electoral laws. ${ }^{31}$

Here we have examined the model in a single-country context over time, but it is applicable to a variety of contexts. In particular, the other countries of Eastern Europe would be excellent cases for further testing the applicability of the officeseeking model. Recent electoral system changes have occurred in the Czech Republic, Slovakia, and Lithuania. These changes and the general pattern of party and electoral system change since transition could be examined using the framework developed here. While it has not experienced a recent manipulation, a more stable institutional system such as Hungary's could be examined as a contrasting case.

\section{Acknowledgments}

We thank Anna Gwiazda for superb research assistance and for comments, and Michael Bernhard, John Ishiyama, Marek Kaminski, Frances Millard, John Schiemann, and Josh Tucker for helpful suggestions. We also thank Hanna Popowska of the Library and Information Services Division of the Polish Sejm for invaluable help with legislation and roll-call voting. A replication data set for this paper consisting of interview transcripts, survey data, and parliamentary faction data are available from the authors upon request.

Manuscript submitted October 25, 2002

Final manuscript received August 18, 2003

\section{References}

Bawn, Kathleen. 1993. "The Logic of Institutional Preferences: German Electoral Law as a Social Choice Outcome." American Journal of Political Science 37(4): 965-89.

Benoit, Kenneth. 2000. "Which Electoral Formula is the Most Proportional? A New Look with New Evidence.” Political Analysis 8(4): 381-88.

Benoit, Kenneth. 2004. "Models of Electoral System Change." Electoral Studies. In press.

Benoit, Kenneth, and John W. Schiemann. 2001. "Institutional Choice in New Democracies: Bargaining Over Hungary's 1989 Electoral Law.” Journal of Theoretical Politics 13(2): 159-88.

Boix, Carles. 1999. "Setting the Rules of the Game: The Choice of Electoral Systems in Advanced Democracies.” American Political Science Review 93(3): 609-24.

Brady, David, and Jongryn Mo. 1992. "Electoral Systems and Institutional Choice: A Case Study of the 1988 Korean Elections." Comparative Political Studies 24(4): 405-30.

Chan, Kenneth Ka-Lok. 2001. "Idealism versus Realism in Institutional Choice: Explaining Electoral Reform in Poland.” West European Politics 24(3): 65-88.

Colomer, Josep, and Margot Pascual. 1994. "The Polish Games of Transition." Communist and PostCommunist Studies 27(3): 275-93.

\footnotetext{
${ }^{31}$ For example, this is the approach of Chan (2001) who concludes that the 1993 electoral law resulted from a combination of idealism and realism. The examination of roll-call data examined here suggests quite clearly that self-interest played a far more exclusive role.
} 
Chrusciak, Ryszard. 1999. System Wyborczy I Wybory W Polsce 1989-1998. [The Polish Electoral System and the 1989-1998 Elections: Parliamentary Disputes and Discussions.] Warsaw: Elipsa Warszawa.

Elster, J., C. Offe, and U. K. Preuss. 1998. Institutional Design in Post-Communist Societies. Cambridge: Cambridge University Press.

Ekiert, Grzegorz. 1992. "Peculiarities of Post-communist Politics: The Case of Poland." Studies in Comparative Communism 24(4): 341-61.

Gebethner, Stanislaw. 1996. "Proportional Representation versus Majoritarian Systems: Free Elections and Political Parties in Poland, 1989-1991." In Institutional Design in New Democracies: Eastern Europe and Latin America, eds. Arend Lijphart and Carlos Weisman. Boulder: Westview, pp. 59-75.

Gebethner, Stanislaw. 1997. "Free Elections and Political Parties in Transition to Democracy in Central and Southeastern Europe.” International Political Science Review 18(4): 381-99.

Gebethner, Stanislaw. 2000. Interview with Jacqueline Hayden. March 23.

Geddes, B. 1996. "Initiation of New Democratic Institutions in Eastern Europe and Latin America." In Institutional Design in New Democracies: Eastern Europe and Latin America, eds. Arend Lijphart and Carlos Weisman. Boulder: Westview, pp. 14-52.

Hayden, Jacqueline. 2001. "Explaining the collapse of communism in Poland: How the strategic misperception of Round Table negotiators produced an unanticipated outcome." The Journal of Communist Studies and Transition Politics 17(4): 108-29.

Ishiyama, John T. 1997. "Transitional Electoral Systems in Post-communist Eastern Europe.” Political Science Quarterly 112(1): 95-115.

Jasiewicz, Krzysztof. 1994. "The Choice of Electoral Systems and the Politics of Transition in Eastern Europe, 1989-1993.' Presented at the Workshop on Elections, Political Reform, and Democratization, Institute on Western Europe, Columbia University.

Kadane, Joseph B. 1972. "On the division of the question.” Public Choice 13: 47-54.

Kaminski, Marek M. 1999. "How Communism Could Have Been Saved: Formal Analysis of Electoral Bargaining in Poland in 1989.” Public Choice 98: 83-109.

Kaminski, Marek M. 2001. "Do Parties Benefit from Electoral Manipulation? Electoral Laws and Heresthetics in Poland, 1989-1993." Presented at the ECPR General Conference, University of Kent, Canterbury.

Kitschelt, Herbert. 1992. "Explaining the Choice of Electoral Laws in New Democracies: The Experience of Southern and Eastern Europe." Presented at the 8th International Conference of Europeanists, Council for European Studies, Chicago.

Kitschelt, Herbert, Zdenka Mansfeldova, Radoslaw Markowski, and Gábor Tóka. 1999. PostCommunist Party Systems: Competition, Representation, and Inter-party Cooperation. Oxford: Oxford University Press.

Laver, Michael, and Kenneth Shepsle. 1996. Making and Breaking Governments: Cabinets and Legislatures in Parliamentary Democracies. Cambridge: Cambridge University Press.

Lijphart, Arend. 1992. "Democratization and Constitutional Choices in Czechoslovakia, Hungary and Poland 1989-1991.” Journal of Theoretical Politics 4(2): 207-23.

Lijphart, Arend. 1994. Electoral and Party Systems: A Study of Twenty-Seven Democracies 1945-1990. New York: Oxford University Press.

Litynski, Jan. 2000. Interview with Jacqueline Hayden. March 19.

Millard, Frances. 1994. "The Shaping of the Polish Party System, 1989-1993." East European Politics and Societies 8(3): 467-94.

Olson, David M. 1993. "Compartmentalized Competition: The Managed Transitional Election System of Poland." Journal of Politics 55(2): 415-41.

Raciborski, Jacek. 2000. Interview with Jacqueline Hayden. March 21.

Remington, Thomas F., and Steven S. Smith. 1996. "Institutional Design, Uncertainty, and Path Dependency during Transition: Cases from Russia." American Journal of Political Science 40(4): $1253-79$. 
Simon, Maurice D. 1996. "Institutional Development of Poland's Post-Communist Sejm: A Comparative Analysis." In The New Parliaments of Central and Eastern Europe, eds. David M. Olson and Philip Norton. Journal of Legislative Studies, Special Issue 2(1): 60-81.

Staniszewska, Grazyna. 1999. Interview with Jacqueline Hayden. May 6.

Tsebelis, George. 1990. Nested Games: Rational Choice in Comparative Politics. Berkeley: University of California Press.

Vinton, Louisa. 1993. "Poland's Political Spectrum on the Eve of the Elections." RFE/RL Report 2(36): 1-221.

Winczorek, Piotr. 2000. Interview with Jacqueline Hayden, March 20.

Kenneth Benoit is Lecturer in Political Science, Trinity College, Dublin 2, Ireland (kbenoit@tcd.ie). Jacqueline Hayden is Lecturer in Irish and Comparative Politics in the Department of Politics, University College Dublin, Belfield, Dublin 4, Ireland (jacqueline.hayden@ucd.ie). 